\title{
Revelation of New Compound from Ethanolic Extract of Fragaria $x$ ananassa var. Lembang
}

\author{
Desak Gede Sri Andayani ${ }^{1 *}$, Puspa Dewi Narrij Lotulung ${ }^{2}$, Anny Sulaswaty $^{2}$, Nur Qaanitaati ${ }^{3}$, \\ Desak Gede Tirta Andini ${ }^{4}$, Rahmaniar Mulyani ${ }^{3}$, Eva Nursyifa ${ }^{3}$ \\ ${ }^{1}$ Research Unit for Clean Technology-Indonesian Institute of Sciences, Bandung, Indonesia \\ ${ }^{2}$ Research Centre for Chemistry-Indonesian Institute of Sciences, Puspiptek Serpong, Tangerang, Indonesia \\ ${ }^{3}$ Jenderal Achmad Yani University, Bandung West Java, Indonesia \\ ${ }^{4}$ Faculty of Science and Technology, Airlangga University, Surabaya, Indonesia
}

\begin{abstract}
Fragaria $x$ ananassa (strawberry) is a subtropical plant that can adapt well in tropical highlands. Fragaria $x$ ananassa have been widely used to cope with health problems. The active compound component of secondary metabolites contained in Fragaria $x$ ananassa has the potential as an antioxidant. This research is done to isolate secondary metabolites from extract of Fragaria $x$ ananassa fruits. Extract Fragaria $x$ ananassa was produced by maceration using ethanol as the solvent. Separation and isolation compound were carried out using Vacuum Liquid Chromatography (VLC) and Gravity Column Chromatography (GCC) guided by Thin Layer Chromatography (TLC) using hexane: ethyl acetate (3:7) as the eluent. The flavonoid compound was determined by the total content of phenolic and flavonoid in extract of Fragaria $x$ ananassa fruits. The results of total phenolic content and total flavonoid content were $0.1130 \mathrm{mg} / \mathrm{g}$ and $0.0112 \mathrm{mg} / \mathrm{g}$, respectively. The alkaloid compound was determined by Dragendorff testing. The elucidation of the structure by Fourier Tansform Infrared (FTIR), Nuclear Magnetic Resonance (NMR), and Liquid Chromatography Mass Spectrometry (LCMS) showed that the active compound contained in the secondary metabolite of extract ethanol from Fragaria $x$ ananassa is 3-Cyclopentyl-5-(1-hydroxyethyl)1,6-dihydro-7H-pyrazolo[4,3-d]pyrimidin-7-one.
\end{abstract}

Keywords: Fragaria x ananassa extract, flavonoid, alkaloid, total phenolic and flavonoid content, FTIR, NMR, LCMS.

\section{INTRODUCTION}

The natural product isolation researches are growing through the decades. The success story of Paclitaxel from Taxus brevifolia as an anticancer drug on clinical trial induces researchers discovering natural products or its metabolites as novel chemopreventive agents. Several Indonesian natural products such as Caesalpinia sappan, Cinnamomum burmanii, and Nerium indicum have been explored their distinct chemopreventive mechanism on cancer cell (Larasati, et al., 2014; Lestari, et al., 2017; Utomo, et al., 2018). However, the lack of identification about the secondary metabolite contribute on its chemopreventive activity impacts on

Submitted: September 13, 2019

Revised: November 11, 2019

Accepted: November 11, 2019

*Corresponding author: desakgedesa@gmail.com 
the bias standard for the application of certain natural products. Therefore, the revelation of secondary metabolite of Indonesian natural products need to be urged further.

Fragaria $x$ ananassa, commonly known as strawberry is widely found in Indonesia at tropical highland areas with a cool temperature, especially in Ciwidey, Garut, and Lembang, West Java (Aristya, et al., 2019). Ko, et al. (2017) reports that Fragaria $x$ ananassa Duch. in South Korea contains anthocyanin, alkaloid, flavanols, lignans, and Ellagitannins. Interestingly the alkaloid compound, Cinchonine exhibited a promising anticancer activity highlighting the important of Fragaria $x$ ananassa as source of herbal medicine (Jin, et al., 2018; Qi, et al., 2017). Due to the lack of information about the secondary metabolite information of Indonesian Strawberry, we aim to identify the secondary metabolite of the fruit section of Fragariax ananassa var. Lembang.

\section{MATERIALS AND METHODS}

\section{Chemicals and reagents}

The sample used in this study was Fragaria $x$ ananassa flour derived from dried Fragaria $x$ ananassa fruit, ethanol p.a (Merck, Darmstadt, Germany), methanol p.a (Merck), acetone (Merck), ethyl acetate (Merck), n-hexane (Merck), reagent Folin-Ciocalteu (Merck), gallic acid (Sigma-Aldrich, St Louis, USA), quercetin (Sigma-Aldrich), $\mathrm{Na}_{2} \mathrm{CO}_{3}$ (Merck), Aluminum chloride $\left(\mathrm{AlCl}_{3}\right)$ (Sigma-Aldrich), $\mathrm{CH}_{3} \mathrm{COOK}$ (Merck), distilled water, bi-distilled water. Merck 60 silica gel $(0.2-0.5 \mathrm{~mm})$, Merck 60 G. silica gel. UV-Vis spectrophotometer (Hitachi U-2800, Marunouchi, Tokyo, Japan). A set of Vacuum Liquid Chromatography (VLC) tools and a set of gravity column tools, column glass, Thin Layer Chromatography (TLC) plates.

\section{Preparation of Extract}

The fresh Fragaria x ananassa fruits from Lembang, Bandung were dried by oven (Memmertt $\mathrm{GmbH}+\mathrm{Co}$. KG, Schwabach, Germany) at $50^{\circ} \mathrm{C}$ for three days until the water contain was $6-8 \%$. The dried Fragaria $x$ ananassa fruits were blended at high speed at $300 \mathrm{rpm}$, filtered by sieve shaker with 60-70 mesh, then macerated with ethanol p.a. for three days until the solution became clear to obtain ethanolic extract of Fragaria $x$ ananassa var. Lembang (EFAL).

\section{Isolation by Vacuum Liquid Chromatography and Gravity Column Chromatography}

In order to obtain the best separation, we performed VLC and Gravity Column Chromatography (GCC). For VLC method, 50 grams of EFAL was dissolved and fractioned in solvent system containing n-hexane:ethyl acetate then finally eluted by methanol. For GCC method, about 10 grams of EFAL was fractionated by n-hexane: ethyl acetate $(3: 7)$ as the solvent system. The isolated spot then was characterized by FTIR, ${ }^{1} \mathrm{H}-\mathrm{NMR},{ }^{13} \mathrm{C}-\mathrm{NMR}$, and LCMS.

\section{Qualitative Test of Flavonoid Content}

About $100 \mathrm{mg}$ of magnesium powder was put into a test tube then added with $1 \mathrm{~mL}$ of $2 \mathrm{M}$ $\mathrm{HCl}$ and $3 \mathrm{~mL}$ of amyl alcohol. A little amount of EFAL was added and shake to the test tube, then the color change was observed.

\section{Qualitative Test of Alkaloid Content}

A small amount of EFAL was put in the test tube, then added with 10 drops of $\mathrm{H}_{2} \mathrm{SO}_{4} 2 \mathrm{M}$ and Meyer Reagent. The formation of sediment and color changes were observed to identify the presence of alkaloid content.

\section{Total Phenolic Content Assay (TPC)}

Determination of total phenol content was determined using the Folin-Ciocalteu method using gallic acid as standard according to Singleton and Rossi (1965) with slight modifications.

Measurement of Gallic Acid Standard

In amount of $10 \mathrm{mg}$ Gallic acid was dissolved by $10 \mathrm{~mL}$ of methanol p.a., then diluted into various concentration $(10,20,30,40$, and $50 \mathrm{ppm})$. 
Folin-Ciocalteau reagent was added to gallic acid standard solution followed with $4 \mathrm{~mL}$ of $\mathrm{Na}_{2} \mathrm{CO}_{3}$ $7 \%$, then diluted by distillated-water to a volume of $10 \mathrm{~mL}$. The solution was incubated for 30 minutes at $45^{\circ} \mathrm{C}$. The absorbance of the solution is measured by UV-Vis spectrophotometry at $765 \mathrm{~nm}$.

\section{Measurement the Total Phenol Content of EFAL}

One hundred milligrams of EFAL was dissolved by $10 \mathrm{~mL}$ of methanol p.a., added by $4 \mathrm{~mL}$ of $\mathrm{Na}_{2} \mathrm{CO}_{3} 7 \%$, then diluted by distilled water. The solution was incubated for 30 minutes at $45^{\circ} \mathrm{C}$. The absorbance of the solution is measured at $765 \mathrm{~nm}$. All the tests were performed in duplicates. Calculation of total phenol content using the following formula:

$$
\mathrm{TPC}=(\mathrm{c} . \mathrm{V}) / \mathrm{m}
$$

Where $\mathrm{c}$ is the concentration of phenol in the extract, $\mathrm{V}$ is the volume of extract in the test solution and $\mathrm{m}$ is the weight of the extract weighed. The phenol value was expressed as mg Gallic Acid Equivalent (GAE)/g extract.

\section{Total Flavonoid Content Assay (TFC)}

Determination of total flavonoid content was carried out by spectrophotometric using quercetin as the standard refers to (Ahmad, et al., 2014; Chang, et al., 2002) with some modifications. Measurement of Quercetin Standard

In amount of $10 \mathrm{mg}$ of quercetin was dissolved by $10 \mathrm{~mL}$ of methanol p.a., then diluted into various concentrations $(10,20,30,40$, and $50 \mathrm{ppm})$. Each standard quercetin solution was added by $3 \mathrm{ml}$ of methanol, $0.2 \mathrm{~mL} \mathrm{AlCl} \mathrm{H}_{3} 10 \%, 0.2 \mathrm{~mL}$ potassium acetate, then diluted by distilled water. The sample was stored in a dark place for 30 minutes at room temperature, then measured the absorbance by a UV-Vis spectrophotometry at $431 \mathrm{~nm}$.

\section{Measurement of Total Flavonoid Content of EFAL}

The $100 \mathrm{mg}$ of EFAL was dissolved with $10 \mathrm{~mL}$ methanol p.a. Each sample solution was taken $1 \mathrm{~mL}$, then added by $3 \mathrm{~mL}$ of methanol, 0.2 $\mathrm{mL} \mathrm{AlCl}_{3} 10 \%, 0.2 \mathrm{~mL}$ potassium acetate and diluted bidistilled water to a volume of $10 \mathrm{~mL}$. The sample was stored in a dark place for 30 minutes at room temperature. The absorbance of the solution was measured by a UV-Vis spectrophotometry at $431 \mathrm{~nm}$. The sample solution was replicated twice. Calculation of total flavonoids content using the following formula:

$$
\mathrm{TFC}=(\mathrm{c} . \mathrm{V}) / \mathrm{m}
$$

Where $\mathrm{c}$ is the concentration of phenol in the extract, $\mathrm{V}$ is the volume of extract in the test solution and $\mathrm{m}$ is the weight of the extract weighed. The phenol value is expressed as mg Quercetin Equivalent $(\mathrm{QE}) / \mathrm{g}$ extract.

\section{RESULTS}

\section{Extraction and Phytochemical Identification}

Identification of secondary metabolite of certain variety of Fragaria $x$ ananassa var. Lembang purposes to inform its distinct profile compared to other varieties. In addition, the information of isolated compound can be used as the database of lead compound candidates for chemopreventive agent discovery. First, we performed the ethanolic extraction to get EFAL and successfully obtained $5.102 \%$ yield (Figure 1). The TLC analysis then was conducted by n-hexane: ethyl acetate and revealed spot detected under at UV light $254 \mathrm{~nm}$ but not at $366 \mathrm{~nm}$ (Figure 1). This shows that the compound has at least two conjugated double bonds but does not have an auxochrome group in its structure. By using phytochemical test, we also confirmed that EFAL contained flavonoid and alkaloid (Tabel 1). The obtained extract was then fractioned to get the isolated compound.

\section{Total Phenolic Content}

Total content of phenolic compounds in the sample was determined using the colourimetric method with gallic acid as a standard. Gallic acid is 
a hydroxybenzoic derivative and belongs to simple, stable and pure phenol acid. Reactions that occur can be seen from the colour changes in the sample. The phenol compound in the sample reacts with a specific reagent Folin-Ciocalteu which produces complex blue compounds (Schofield, et al., 2001). The blue chromophore formation reaction involves the phosphotungstic phosphomolibdenum reaction (Gülçin, 2005). After several calculation we found that total phenolic contained on EFAL was $0.1130 \pm 0.0254 \mathrm{mg} \mathrm{GAE} / \mathrm{g}$ extract (Table 5).

\section{Total Flavonoid Content}

Determination of total flavonoid content using the spectrophotometer method with Quercetin as standard. The reaction that occurs can be seen from the colour change of the sample solution when added to the $\mathrm{AlCl}_{3}$ solution, this occurs because there is the formation of complex compounds with flavonoids which produce a more yellow colour so that the absorbance can be read in the visible area. After that, a potassium acetate solution was added to maintain the wavelength shift in the visible area. After several calculation, EFAL contained $0.0112 \pm 0.0139 \mathrm{mg} \mathrm{QE} / \mathrm{g}$ extract (Table 6).

Yield (\%) of extract of Fragaria x ananassa var Lembang

$\%=$ Weight of EFAL/Fresh Fragaria $\mathrm{x}$ ananassa var $\mathrm{x} 100$

$=524.53 \mathrm{Gram} / 10280 \mathrm{Gram} \times 100$

$=5.102 \%$

\section{Vacuum Liquid Chromatography (VLC)}

Isolation using Vacuum Liquid Chromatography (VLC) and Gravitational Column Chromatography (GCC)

VLC and GCC methods were carried out to separate secondary metabolites based on its polarity. From 10 to 50 grams extract of Fragaria $x$ ananassa var Lembang dissolve with methanol then impregnated into silica gel 60 using eluent ratio n-hexane-ethyl acetate (Table 4) which increased its polarity in gradient from $0-100 \% / 100 \%-0$ and finally eluted with methanol. Analysis using Thin
Layer Chromatography at a wavelength of $254 \mathrm{~nm}$ and staining with $\mathrm{H}_{2} \mathrm{SO}_{4}$, showed the elution with hexane: ethyl acetate (3:7) showed significant separation (Figure 2).

\section{Characterization of secondary metabolite content}

The characterization of secondary metabolite from the extract was carried out by FTIR, ${ }^{1} \mathrm{H}$, ${ }^{13} \mathrm{C}$ NMR and LCMS (Figure 3). The FTIR spectrum (Figure 7) shows typical compound of alkyne: $\mathrm{C}-\mathrm{H}$ at $600 \mathrm{~cm}^{-1}, \mathrm{RC} \equiv \mathrm{CH}, \mathrm{HC} \equiv \mathrm{CH}, \mathrm{RCH}=\mathrm{CHR}$ (cis) at $667 \mathrm{~cm}^{-1}, \mathrm{CC} \equiv \mathrm{C}, \mathrm{RC} \equiv \mathrm{CH}$ at $2159 \mathrm{~cm}^{-1}$, aromatic: $\mathrm{C}-\mathrm{H}$ at $667 \mathrm{~cm}^{-1}, \mathrm{C}-\mathrm{O}$ at $1076 \mathrm{~cm}^{-1}$ and 1393 $\mathrm{cm}^{-1} \mathrm{~N}-\mathrm{H}$ at $3270 \mathrm{~cm}^{-1}$, phenol: $\mathrm{O}-\mathrm{H}$ at $667 \mathrm{~cm}^{-1}$, $\mathrm{C}-\mathrm{O}$ at $1147 \mathrm{~cm}^{-1}$, amine: $\mathrm{N}-\mathrm{H}$ at $2341 \mathrm{~cm}^{-1}, 2360$ $\mathrm{cm}^{-1}, 2940 \mathrm{~cm}^{-1}, 3270 \mathrm{~cm}^{-1}, 667 \mathrm{~cm}^{-1}, 1592 \mathrm{~cm}^{-1}$, $\mathrm{C}-\mathrm{N}$ at $1076 \mathrm{~cm}^{-1}, 3270 \mathrm{~cm}^{-1} . \mathrm{C}=\mathrm{N}, \mathrm{C}=\mathrm{O}$ at 1592 $\mathrm{cm}^{-1}$, aliphatic: $\mathrm{N}-\mathrm{H}$ at $3270 \mathrm{~cm}^{-1}$, alkene: $\mathrm{C}=\mathrm{C}$ at $1976 \mathrm{~cm}^{-1}, \mathrm{C}-\mathrm{H} \mathrm{C}\left(\mathrm{CH}_{3}\right)_{3}$ at $1393 \mathrm{~cm}-, \mathrm{RCH}=\mathrm{CH}^{2}$, $\mathrm{C}\left(\mathrm{CH}_{3}\right)_{3}$ at $930 \mathrm{~cm}-1$, carboxyclic acid: $\mathrm{C}=\mathrm{O}$ at $1763 \mathrm{~cm}^{-1}, 2940 \mathrm{~cm}-1, \mathrm{O}-\mathrm{H}$ at $1393 \mathrm{~cm}^{-1}$, hydrocarbon: C-H, O-H at $2940 \mathrm{~cm}^{-1}$, O-H aldehyde: O-H at $1393 \mathrm{~cm}^{-1}$, alcohol saturated: $\mathrm{C}-\mathrm{O}$, alicyclic: 5 -or 6-membered ring, $\alpha$-unsaturated, $\alpha, \beta$-unsaturated acid, cyclic at $1076 \mathrm{~cm}^{-1}$, vinyl acetate: $\mathrm{C}-\mathrm{O}$, phenyl acetate, $\mathrm{ROH}$ at $1147 \mathrm{~cm}^{-1}$, thiazole, guanidine: $\mathrm{C}=\mathrm{N}, \beta$-diketone, carboxyl anion : $\mathrm{C}=\mathrm{O}$ at $1592 \mathrm{~cm}^{-}$ 1, peroxide, acyl, aroyl: $\mathrm{C}=\mathrm{O}$, ester, lactone, aliphatic: $\mathrm{C}=\mathrm{O}$ at $1763 \mathrm{~cm}^{-1}$, isocyanidine, isocyanate, thiocyanate, isothiocyanate: $\mathrm{C} \equiv \mathrm{N}$ at $2030 \mathrm{~cm}^{-1}$.

The LCMS spectrum (Figure 4) shows a strong molecular ion $\left(\mathrm{M}^{+}, \mathrm{m} / \mathrm{e}\left(248.25+\mathrm{H}^{+}\right)\right)$. The ${ }^{1} \mathrm{H}$ NMR spectrum (Figure $4 \mathrm{a}$ ) shows typical compound of aldehyde: $\mathrm{R}-\mathrm{C}=\mathrm{OH}$ at $9.5 \mathrm{ppm}$, aromatic: $\mathrm{ArH}$ at $7.3-6.5 \mathrm{ppm}$, phenolic: $\mathrm{ArOH}$, amino: $\mathrm{RNH}_{2}$ at 4.8 ppm, $\mathrm{R}_{2} \mathrm{C}=\mathrm{CH}_{2}$, amino $\mathrm{RNH}_{2}$ at 4.6 ; 4.5 and $4.4-4.0 \mathrm{ppm}, 1,5 \mathrm{ppm}, 2 \mathrm{ppm}$, 1.2-1.3 ppmether, ester, $\mathrm{ROCH}_{2} \mathrm{R}, \mathrm{RCOOCH}_{2} \mathrm{R}$, $\mathrm{HOCH}_{2} \mathrm{R}$ at 2, 3.7-3.4 ppm, alkyl $\mathrm{R}_{3} \mathrm{CH}, \mathrm{RCH}_{3}$, at $0.9 \mathrm{ppm}$, hydroxyl $\mathrm{ROH}$ at $0.9 ; 1.2-1.3,1.5 \mathrm{ppm}$, The 13C NMR spectrum (Figure 4b) shows typical compound of aldehyde $\mathrm{RC}=\mathrm{OH}$ at $179.4 \mathrm{ppm}$, anhydride: $\mathrm{RC}=\mathrm{O}-\mathrm{O}-\mathrm{C}=\mathrm{OR}$ at $172.9 \mathrm{ppm}, \mathrm{RC}$ - 
$=\mathrm{O}-\mathrm{O}-\mathrm{C}=\mathrm{OR}, \mathrm{RC}=\mathrm{O}-\mathrm{O}-\mathrm{C}=\mathrm{OR}$ at $153.8 \mathrm{ppm}$, ester: $\mathrm{RC}=\mathrm{O}-\mathrm{OR}$ at $163.2 \mathrm{ppm}, \mathrm{RC}=\mathrm{O}-\mathrm{OR}$ at 172.9 $\mathrm{ppm}, \mathrm{RC}=\mathrm{O}-\mathrm{OR}$ at $153.8 \mathrm{ppm}$, carboxyclic acid: $\mathrm{RC}=\mathrm{O}-\mathrm{OR}$ at $172.9 \mathrm{ppm}, \mathrm{RC}=\mathrm{O}-\mathrm{OR}$ at $163.2 \mathrm{ppm}$, alkene (aromatic) $\mathrm{R}_{2} \mathrm{C}=\mathrm{CR}_{2}$ at $163.2 \mathrm{ppm}, \mathrm{R}_{2} \mathrm{C}=\mathrm{CR}_{2}$ at $153.8 \mathrm{ppm}, \mathrm{R}_{2} \mathrm{C}=\mathrm{CR}_{2}$ at $124-110 \mathrm{ppm}$, aryl (benzene): $\mathrm{C}$ in ring at $153.8 \mathrm{ppm}, 124-110 \mathrm{ppm}$, and $99.2 \mathrm{ppm}$, nitrile: $\mathrm{RC} \equiv \mathrm{N}$ at $124-110 \mathrm{ppm}$, alkyne : $\mathrm{RC} \equiv \mathrm{CR}$ at $61.5-68.5$ and $72-73$ ppm, ether: $\mathrm{R}_{3} \mathrm{C}-\mathrm{O}$ at $72-73$ and $61.5-68.5 \mathrm{ppm}$, amine: $\mathrm{R}_{3} \mathrm{C}-\mathrm{NR}_{2}$ at 61.5-68.5, 57.6-57.5, 52.3-52.7, 49.2, 39.8-30.7, and 20.2-14.2 ppm, ether: $\mathrm{R}_{3} \mathrm{C}-\mathrm{O}$ at $57.6-57.5 \mathrm{ppm}$, alkyl : $\mathrm{RCHR}_{2}, \mathrm{RCH}_{2} \mathrm{R}$ at 52.3-52.7, 57.6-57.5, and 49.2 ppm, alkyl $\mathrm{RCH}_{3}, \mathrm{RCH}_{2} \mathrm{R}, \mathrm{RCHR}_{2}$ at 39.830.7 ppm, alkyl: $\mathrm{RCH}_{3}, \mathrm{RCH}_{2} \mathrm{R}$ at 20.2-14.2 ppm. The elucidation of the structure by FTIR, ${ }^{1} \mathrm{H},{ }^{13} \mathrm{C}$ NMR and LCMS showed that the active compound contained in the secondary metabolite of extract ethanol from Fragaria $x$ ananassa was 3-Cyclopentyl-5-(1-hydroxyethyl)-1,6-dihydro-7H-pyrazolo[4,3- d]pyrimidin-7-one and the molecular weight was $248.29 \mathrm{~g} / \mathrm{mol}$. The molecular structure was showed in Figure 5.

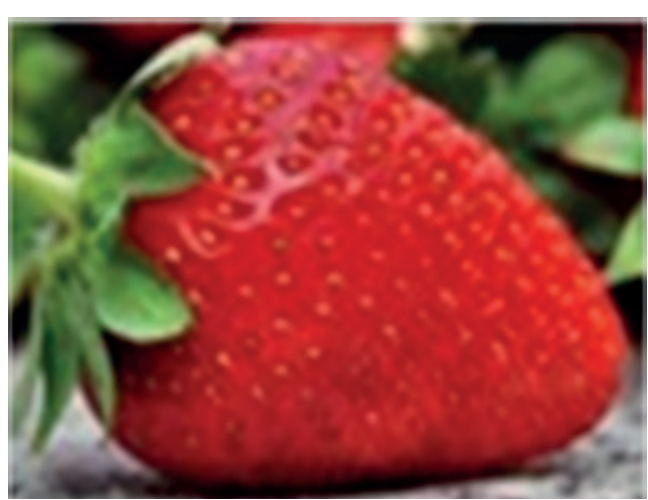

A

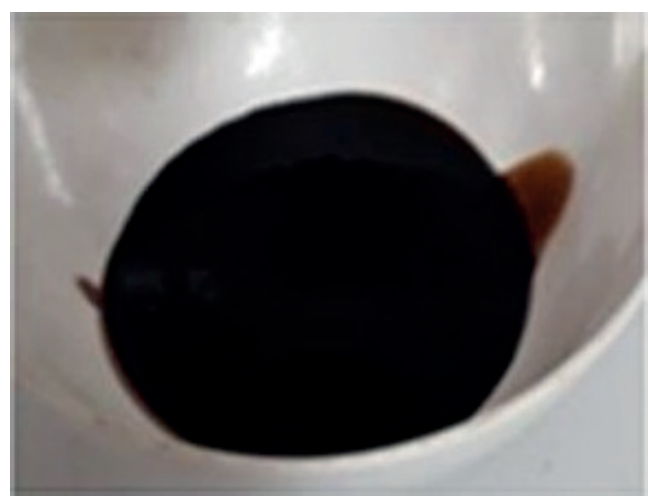

B

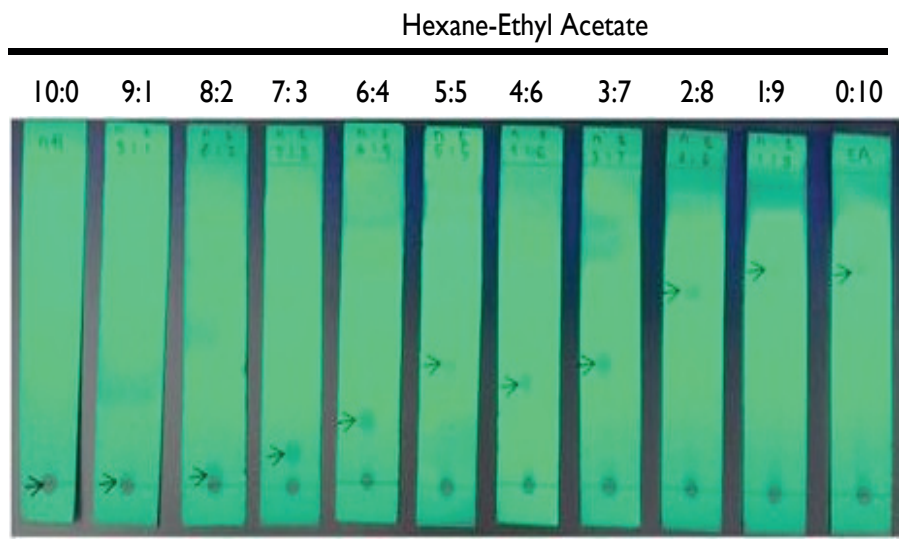

C

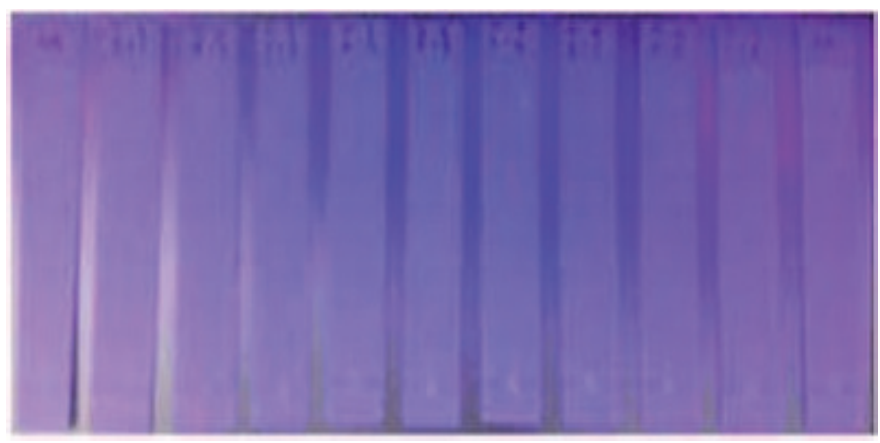

D

Figure I. Fragaria $x$ ananassa var Lembang and its TLC Profile. (A) Fruit of Fragaria $x$ ananassa var Lembang used in this study. (B) Ethanolic extract of Fragaria $x$ ananassa var Lembang. (C). The TLC profile of EFAL under UV $254 \mathrm{~nm}$. (D) The TLC profile of EFAL under UV $366 \mathrm{~nm}$. The arrow indicates the presence of spot. 
Indonesian Journal of Cancer Chemoprevention, October 2019

ISSN: 2088-0197

e-ISSN: 2355-8989

Table I. Result of Flavonoid and Alkaloid Test on Fragaria $x$ ananassa Extracts

\begin{tabular}{llll}
\hline $\begin{array}{c}\text { Phytochemical } \\
\text { Testing }\end{array}$ & Photo & Results & \multicolumn{1}{c}{ Note } \\
\hline Flavonoid & + & $\begin{array}{l}\text { Presence of orange- } \\
\text { colored amyl alcohol } \\
\text { layer }\end{array}$ \\
\hline & & + & $\begin{array}{l}\text { Presence of orange- } \\
\text { colored sediment }\end{array}$ \\
\hline & & & \\
\hline
\end{tabular}

Table 2. Total phenol content of Fragaria $x$ ananassa extract

\begin{tabular}{ccccc}
\hline Sample & $\begin{array}{c}\text { Absorbance } \\
\lambda \mathbf{7 6 5} \mathbf{~ n m}\end{array}$ & $\begin{array}{c}\text { Phenol } \\
\text { concentration } \\
(\mathbf{m g} / \mathbf{m L})\end{array}$ & $\begin{array}{c}\text { Total phenol } \\
\text { content } \\
(\mathbf{m g} \text { GAE/g extract) }\end{array}$ & $\begin{array}{c}\text { The average of total phenol } \\
\text { content } \mathbf{\text { ISD }} \text { (mg GAE/g } \\
\text { extract) }\end{array}$ \\
\hline Ethanol & 0.664 & 45.222 & 0.1310 & $0.1130 \pm 0.0254$ \\
Extract & 0.552 & 32.778 & 0.0950 & \\
\hline
\end{tabular}

Table 3. Total flavonoid content of extract Fragaria $x$ ananassa var lembang

\begin{tabular}{ccccc}
\hline Sample & $\begin{array}{c}\text { Absorbance } \\
\lambda \mathbf{4 3} \mathbf{~ n m}\end{array}$ & $\begin{array}{c}\text { Flavonoid } \\
\text { concentration } \\
(\mathbf{m g} / \mathbf{m L})\end{array}$ & $\begin{array}{c}\text { Total flavonoid } \\
\text { content } \\
(\mathbf{m g} \text { QE/g extract) }\end{array}$ & $\begin{array}{c}\text { The average of total flavonoid } \\
\text { content } \mathbf{S D} \text { (mg QE/g } \\
\text { extract) }\end{array}$ \\
\hline Extract & 0.306 & 3.647 & 0.0211 & $0.0112 \pm 0.0139$ \\
Ethanol & 0.248 & 0.235 & 0.0014 & \\
\hline
\end{tabular}

Table 4. Eluent Ratio VLC

\begin{tabular}{ccc}
\hline Eluent & Ratio & Amount \\
\hline n-hexane : ethyl acetate & $10: 0$ & $2 \times 400 \mathrm{~mL}$ \\
n-hexane : ethyl acetate & $8: 2$ & $3 \times 400 \mathrm{~mL}$ \\
n-hexane : ethyl acetate & $6: 4$ & $3 \times 400 \mathrm{~mL}$ \\
n-hexane : ethyl acetate & $5: 5$ & $2 \times 400 \mathrm{~mL}$ \\
n-hexane : ethyl acetate & $3: 7$ & $3 \times 400 \mathrm{~mL}$ \\
n-hexane : ethyl acetate & $0: 10$ & $3 \times 400 \mathrm{~mL}$ \\
ethyl acetate : methanol & I:I & $4 \times 400 \mathrm{~mL}$ \\
\hline
\end{tabular}

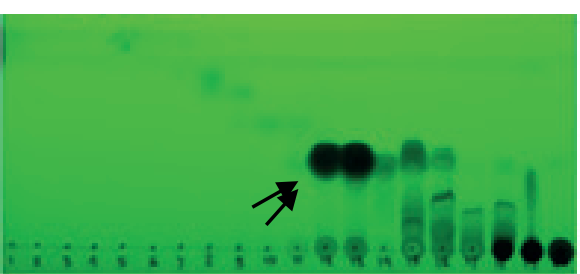

A

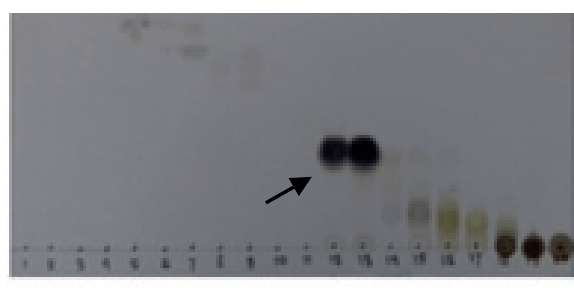

B

Figure 2. Chromatogram of isolate $\mathrm{I} 2$ at (a) $\lambda=254 \mathrm{~nm}$ and (b) coloring with $\mathrm{H}_{2} \mathrm{SO}_{4}$ 


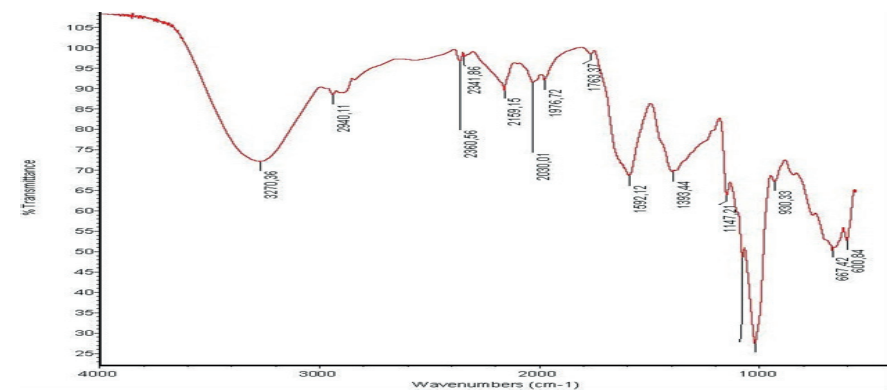

Figure 3. FTIR spectra of Fragaria $x$ ananassa var Lembang extract

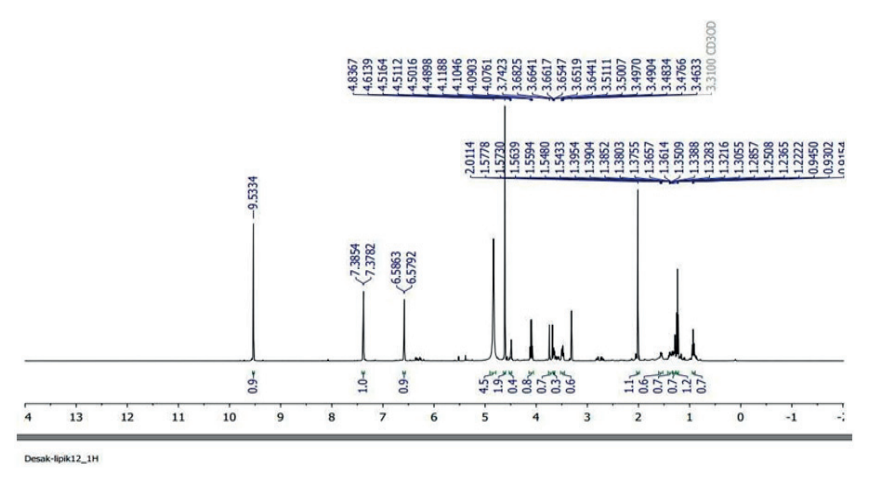

A

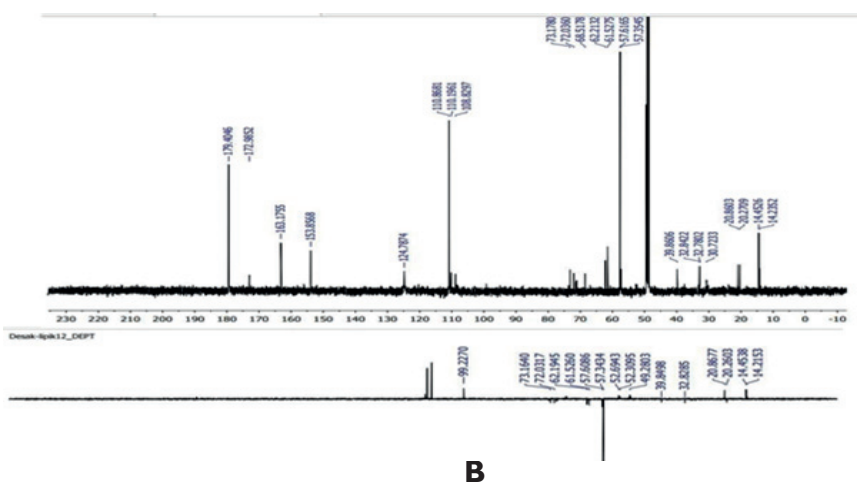

B

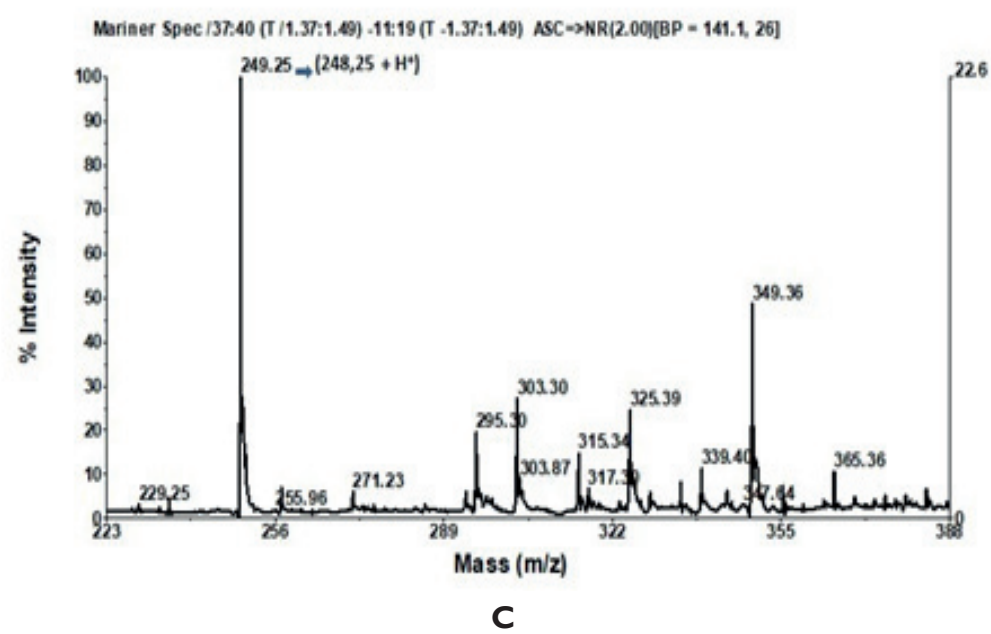

Figure 4. Results of IH (a), I3C (b) NMR and LCMS (c) of Isolate I 2 
<smiles>CC(O)c1nc2c(C3CCCC3)n[nH]c2c(=O)[nH]1</smiles>

Figure 5. 3-Cyclopentyl-5-(I-hydroxyethyl)-I ,6-dihydro-7H-pyrazolo[4,3- d]pyrimidin-7-one
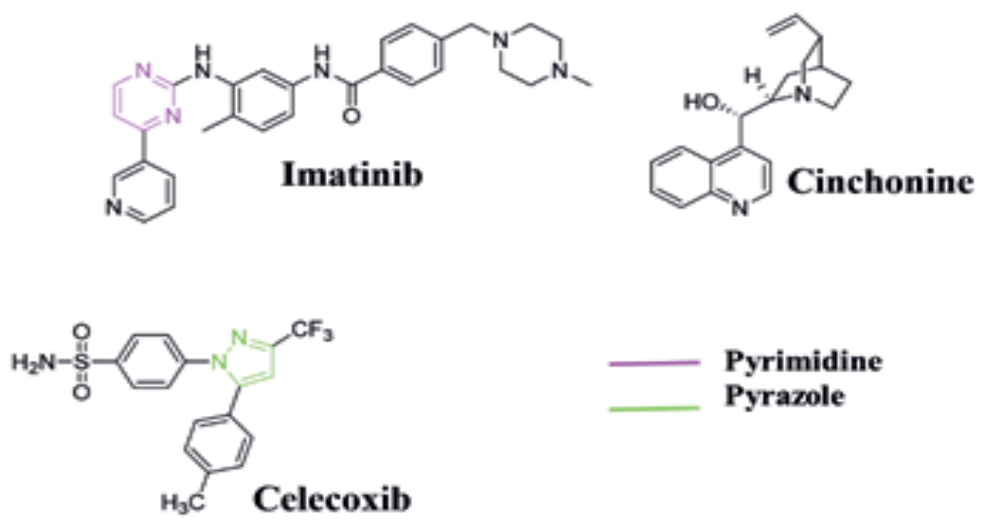

Figure 6. Anticancer agent bearing pyrimidine and pyrazole structure

\section{DISCUSSION}

Strawberry, a delicious fruit consumed both as fresh fruits and processed, may thus be an herbal medicine for many people. Fruits of strawberry contains certain secondary metabolite such as phenolic compounds and alkaloid with promising health effects (Tulipani, et al., 2008). The secondary metabolite of strawberry vary significantly with genotype but it also affected by environmental factur such as humidity, agricultural practice, and sun irradiation (Battino, et al., 2009; Pineli, et al., 2011). From over 19 varieties of Fragaria species in the world, it was Fragaria $x$ ananassa that widely growth on Ciwidey, Lembang Indonesia. Our finding reveal that Fragaria $x$ ananassa var. Lembang contained appropriate amount of phenolic compound and flavonoid which was well known possessing chemopreventive activity through various mechanism.

Here, we also reveal a novel compound from alkaloid contained on Fragaria $x$ ananassa var. Lembang namely, 3-Cyclopentyl-5-(1-hydroxyethyl)-1,6-dihydro-7H-pyrazolo[4,3-d]pyrimidin-7-one. Differ with already known alkaloid Cinchonine, in this compound possessd an interesting feature by the presence of pyrimidine and pyrazole rings, the two electron-rich nitrogen heterocycles contributed on cancer marker binding affinity. Among the reported medicinal attributes of pyrimidine, anticancer activity was the most extensively reported (Kaur, et al., 2015) the Imatinib (Figure 6), the first line therapy for Leukemia contained the pyrimidine ring which contributes to form $\mathrm{H}$ bond with Thr315 on the Abl domain and prevents ATP from reaching its binding site (Manley, et al., 2002). On the other hand, pyrazole ring (Figure 6), a 5-member ring and the most widely explored among azole family also contributes in anticancer activity (Mohamed, et al., 2013). One of the compound bearing pyrazole ring, celecoxib (Figure 6) possessed as anti-inflamatory activity by binding with COX-2. The molecular docking study reported 
that The trifluoromethyl group attached to the pyrazole ring is surrounded by a close hydrophobic cavity and strong electrostatic field with Arg120 (Deb, et al., 2017). Summarizing all of the evidence, we predict that the presence of pyrimidine and pyrazole on one structure of compound 3-Cyclopentyl-5-(1-hydroxyethyl)-1,6-dihydro-7H-pyrazolo[4,3-d]pyrimidin-7-one promoted the potential chemopreventive activity. Further experiment on chemopreventive activity need to be conducted to extend the application of Fragaria $x$ ananassa var Lembang or its isolated compound for more valuable benefits.

\section{CONCLUSION}

The obtained results showed that the quantitative testing of total phenolic and flavonoid content were $0.1130 \mathrm{mg} / \mathrm{g}$ and $0.0112 \mathrm{mg} / \mathrm{g}$ respectively. The qualitative testing of Fragraria $x$ annassa extract was positive contain alkaloid. Structural elucidation by FTIR, ${ }^{1} \mathrm{H}$ and ${ }^{13} \mathrm{C}$ NMR and LCMS showed that the compound is 3-Cyclopentyl-5(1-hydroxyethyl)-1,6-dihydro-7H-pyrazolo[4,3-d]pyrimidin-7-one with molecular formula $\mathrm{C}_{12} \mathrm{H}_{16} \mathrm{~N}_{4} \mathrm{O}_{2}$ and molecular weight of $248.29 \mathrm{~g} / \mathrm{mol}$.

\section{ACKNOWLEDGMENT}

Thank you for the funding provided by Ministry of Research, Technology and Higher Education of Republic of Indon esia through the INSINAS 2018 program from Indonesian Institute of Sciences Flagship Priority in the Field Development of Local Resources Based Functional Food.

\section{REFERENCES}

Ahmad, A., Wisdawati, S. and Asrifa, W., 2014, Study of Antioxidant activity and determination of Phenol and Flavonoid content of Pepino's Leaf extract (Solanum muricatum
Aiton), Int. J. PharmTech Res., 6, 600-606. Aristya, G.R., Kasiamdari, R.S., Setyoningrum, R. and Larasati, B., 2019, Genetic variations of strawberry cultivars of Fragaria $x$ ananassa and Fragaria vesca based on RAPD, Biodiversitas J. Biol. Divers., 20, 770-775.

Battino, M., Beekwilder, J., Denoyes-Rothan, B., Laimer, M., McDougall, G.J. and Mezzetti, B., 2009, Bioactive compounds in berries relevant to human health, Nutr. Rev., 67, S145-S150.

Chang, C.C., Yang, M.H., Wen, H.M. and Chern, J.C., 2002, Estimation of Total Flavonoid Content in Propolis by Two Complementary Colorimetric Methods, J. Food Drug Anal., 10, 178-182.

Deb, P.K., Mailabaram, R.P., Saadh, B.A.-J. and M.J., 2017, Molecular Basis of Binding Interactions of NSAIDs and Computer-Aided Drug Design Approaches in the Pursuit of the Development of Cyclooxygenase-2 (COX-2) Selective Inhibitors, Nonsteroidal Anti-Inflamm. Drugs.

Gülçin, İ. , 2005. The antioxidant and radical scavenging activities of black pepper (Piper nigrum) seeds, Int. J. Food Sci. Nutr., 56, 491-499. Jin, Z.-L., Yan, W., Qu, M., Ge, C.-Z., Chen, X., Zhang, S.F., 2018. Cinchonine activates endoplasmic reticulum stress-induced apoptosis in human liver cancer cells, Exp. Ther. Med. 15, 5046-5050.

Kaur, R., Kaur, P., Sharma, S., Singh, G., Mehndiratta, S., Bedi, P.M.S. and Nepali, K., 2015, Anti-cancer pyrimidines in diverse scaffolds: a review of patent literature, Recent Patents Anticancer Drug Discov., 10, 23-71. Ko, M.J., Jayaramaiah, R.H., Gupta, R., Kim, S.W., An, J.U., Wang, Z., Li, M., Kang, N.J., Hong, K.-P., Kang, J.-S., Kim, S.T. and Choi, Y.W., 2017, Evaluation of Bioactive Compounds in Strawberry Fruits by a Targeted Metabolomic Approach, 궈옝과학기술지 , 35, 805-819. Larasati, Y.A., Putri, D.D.P., Utomo, R.Y., Hermawan, A. and Meiyanto, E., 2014, Combination of Cisplatin and Cinnamon Essential Oil Inhibits HeLa Cells Proliferation through Cell Cycle Arrest, J. Appl. Pharm. Sci., 4, 014-019. 
Lestari, B., Muntafiah, L., Walidah, Z. and Jenie, R.I., 2017, A Comparison of Antimetastatic Activity between Nerium indicum and Cinnamomum burmannii on 4T1 Cells, Indones. J. Cancer Chemoprevention., 8, 85-93. Manley, P.W., Cowan-Jacob, S. W., Buchdunger, E., Fabbro, D., Fendrich, G. , Furet, P., Meyer, T. and Zimmermann, J., 2002, Imatinib: a selective tyrosine kinase inhibitor, Eur. J. Cancer, 38, S19-S27. Mohamed, A.M., El-Sayed, W.A., Alsharari, M.A., Al-Qalawi, H.R.M. and Germoush, M.O., 2013, Anticancer activities of some newly synthesized pyrazole and pyrimidine derivatives, Arch. Pharm. Res., 36, 1055-1065.

Pineli, L. de L. de O., Moretti, C.L., dos Santos, M.S., Campos, A.B., Brasileiro, A.V., Córdova, A.C. and Chiarello, M.D., 2011, Antioxidants and other chemical and physical characteristics of two strawberry cultivars at different ripeness stages, J. Food Compos. Anal., 24, 11-16.

Qi, Y., Pradipta, A.R., Li, M., Zhao, X., Lu, L., Fu, X., Wei, J., Hsung, R.P., Tanaka, K. and Zhou, L., 2017, Cinchonine induces apopto- sis of HeLa and A549 cells through targeting TRAF6, J. Exp. Clin. Cancer Res., 36, 35. Schofield, P., Mbugua, D.M., Pell, A.N., 2001. Analysis of condensed tannins: a review. Anim. Feed Sci. Technol., Tannins:Analysis and Biological Effects in Ruminant Feeds 91, 21-40. Singleton, V.L. and Rossi, J.A., 1965, Colorimetry of Total Phenolics with Phosphomolybdic-Phosphotungstic Acid Reagents, Am. J. Enol. Vitic., 16, 144-158. Tulipani, S., Mezzetti, B., Capocasa, F., Bompadre, S., Beekwilder, J., de Vos, C.H.R., Capanoglu, E., Bovy, A. and Battino, M., 2008, Antioxidants, Phenolic Compounds, and Nutritional Quality of Different Strawberry Genotypes, J. Agric. Food Chem., 56, 696-704.

Utomo, R.Y., Novarina, A., Tirtanirmala, P., Kastian, R.F. and Jenie, R.I., 2018, Enhancement of Cytotoxicity and Apoptosis Induction of Doxorubicin by Brazilein Containing Fraction of Secang (Caesalpinia sappan L.) on T47D Cells, Indones. J. Cancer Chemoprevention, 9, 32-40. 